\title{
STAT3, stem cells, cancer stem cells and p63
}

\author{
Michaela Galoczova* (D), Philip Coates and Borivoj Vojtesek
}

\author{
* Correspondence: \\ michaela.galoczova@mou.cz \\ Regional Centre for Applied \\ Molecular Oncology, Masaryk \\ Memorial Cancer Institute, Zluty \\ kopec 7, 65653 Brno, Czech \\ Republic
}

\begin{abstract}
Signal Transducer and Activator of Transcription 3 (STAT3) is a transcription factor with many important functions in the biology of normal and transformed cells. Its regulation is highly complex as it is involved in signaling pathways in many different cell types and under a wide variety of conditions. Besides other functions, STAT3 is an important regulator of normal stem cells and cancer stem cells. p63 which is a member of the p53 protein family is also involved in these functions and is both physically and functionally connected with STAT3. This review summarizes STAT3 function and regulation, its role in stem cell and cancer stem cell properties and highlights recent reports about its relationship to p63.
\end{abstract}

Keywords: STAT3, Stem cells, Cancer stem cells, p63

This article was specially invited by the editors and represents work by leading researchers.

\section{Background}

Our team is working on expression and functional properties of p63, which is a member of the p53 protein family with diverse roles in carcinogenesis that include tumorsuppressing and oncogenic effects [1-4]. Several recent studies link p63 with STAT3 that is one of the seven members of the Signal Transducer and Activator of Transcription (STAT) family of transcription factors [5]. STAT3 and p63 are important regulators of cell proliferation and survival, and have major roles in the maintenance of stem cells and their differentiation, and are involved in carcinogenesis of many cell types. STAT3 is known to act through its ability to regulate both oncogenes and tumor suppressor genes, as well as influencing tumor microenvironments [6-9]. It exerts a plethora of different and sometimes contrasting functions in normal and transformed cells. This multifaceted function can be partly explained by its involvement in signaling pathways in many different types of cells and conditions [10]. p63 is most commonly linked with epithelial malignancies, particularly squamous cancers [9, 11]. Like STAT3, p63 acts to transcriptionally regulate a wide variety of genes in cancer that are involved in proliferation, survival and differentiation, and also has major roles in cell adhesion and motility [3, 4]. This review will provide basic information about STAT3 and its regulation and will focus on its role(s) in stem cells and cancer stem cells. We will also briefly discuss its relationship with p63 which is also involved in many pathways connected with self-renewal and differentiation properties of stem cells and cancer stem cells $[8,12,13]$.

(c) The Author(s). 2018 Open Access This article is distributed under the terms of the Creative Commons Attribution 4.0 International License (http://creativecommons.org/licenses/by/4.0/), which permits unrestricted use, distribution, and reproduction in any medium, provided you give appropriate credit to the original author(s) and the source, provide a link to the Creative Commons license, and indicate if changes were made. The Creative Commons Public Domain Dedication waiver (http://creativecommons.org/ publicdomain/zero/1.0/) applies to the data made available in this article, unless otherwise stated. 


\section{Structure of STAT3}

All STATs share similar functional domains, including an N-terminal domain, a coiled coil domain which enables protein-protein interactions, a central DNA-binding domain, a linker domain that affects DNA-binding stability and a classic SRC homology 2 (SH2) domain. STAT3 has two important phosphorylation sites - a tyrosine residue at amino acid position 705 (Tyr705) within the SH2 domain and a serine phosphorylation site at position 727 (Ser727) within the C-terminal transactivation domain, which is absent in the alternatively spliced STAT3 $\beta$ variant [14].

The full-length isoform (isoform 1), STAT3 $\alpha$, which is the most commonly expressed form, encodes a protein of predicted mass $88 \mathrm{kDa}[15,16]$. The truncated STAT3 $\beta$ isoform (isoform 3) $(83 \mathrm{kDa})$ is produced by alternative splicing of a 3' splice acceptor site in exon 23 of the STAT3 gene. STAT3 $\alpha$ is 770 amino acids in length and STAT3 $\beta$ is identical in sequence with the exception of 55 amino acids at the $\mathrm{C}$-terminal tail that are replaced with a unique seven amino acid sequence (Fig. 1) [15-17]. STAT3 $\beta$ was initially thought to be a negative regulator of STAT3 $\alpha$ target genes because it lacks the transactivation domain [15]. However, it was demonstrated in vivo that STAT3 $\beta$ is not a dominant negative factor and seems to be involved in lipopolysaccharide-mediated induction of the interleukin-10 promoter [18]. Another two isoforms have been described, produced by limited proteolysis during granulocytic differentiation; a $72 \mathrm{kDa}$ C-terminal-truncated form known as STAT3 $\gamma$, and a $64 \mathrm{kDa}$ truncated isoform known as STAT3 $\delta$ [19-21]. Another isoform (isoform 2) was identified with a deleted amino acid at position 701 (Del-Ser701) by global phosphoproteomic approaches [22, 23]. The validity and function of these latter variants remains to be determined.

\section{Regulation of STAT3}

STAT3 activity is regulated by multiple activators and negative regulators, reflecting its varied functions in a wide range of cell types. The main mechanism of activation is phosphorylation of Tyr705 by upstream kinases, although residue Ser727 can also be phosphorylated. Moreover, STAT3 may be transcriptionally active in its unphosphorylated form and its activity is regulated also by other posttranslational modifications such as acetylation, methylation or ubiquitination. Negative regulation of STAT3 is

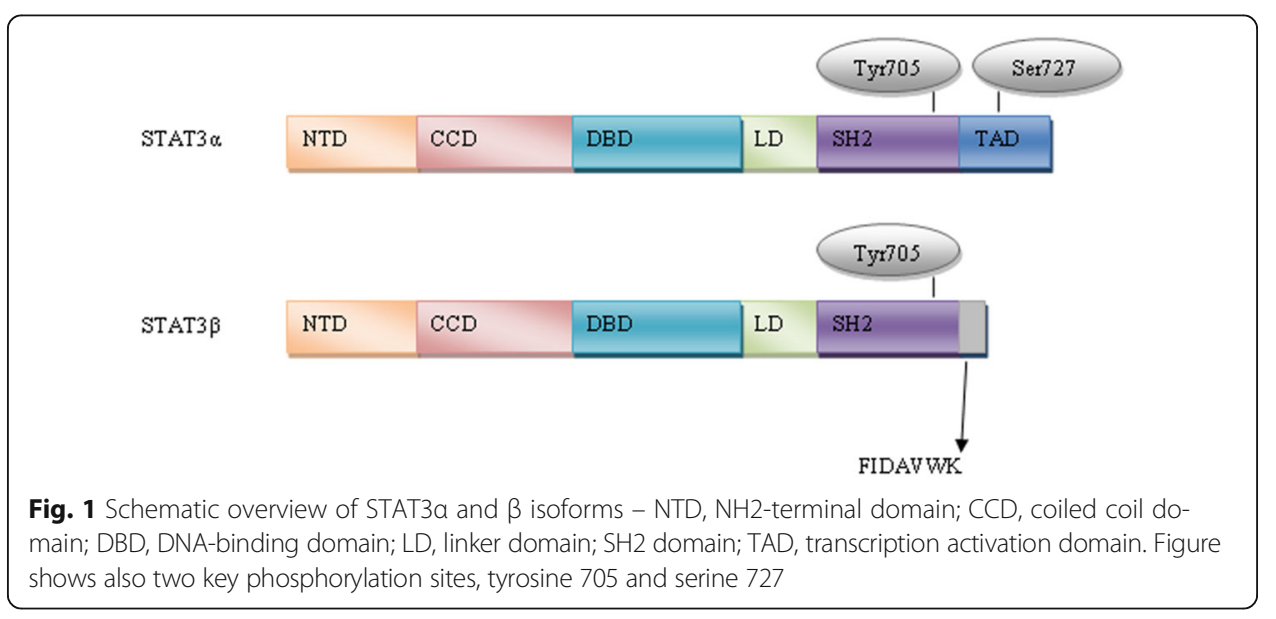


provided by protein phosphatases and specific protein inhibitors - Suppressors of Cytokine Signaling (SOCS) and Protein Inhibitors of Activated STAT (PIAS). Furthermore, its expression is regulated by several miRNAs.

\section{Activation of STAT3}

STAT3 is mainly activated by phosphorylation of the conserved Tyr705 residue, which leads to dimerization by reciprocal phosphotyrosine-SH2 interactions of two monomers [24]. Activated STAT3 dimers translocate to the nucleus through interactions with importins and bind to the GAS (Interferon- $\gamma$-Activated Sequence) motif within target gene promoters to activate transcription [25-27]. Most STATs including STAT3 bind to GAS motifs with a consensus TTCN ${ }_{2-4}$ GAA [28]. The STAT3 consensus binding site is illustrated in Fig. 2 [29]. Besides STAT3 homodimers, STAT1/STAT3 heterodimers have been reported, with transcriptional potential that differs from STAT1 or STAT3 homodimers [30].

STAT3 Tyr705 phosphorylation is primarily mediated by Janus Kinases (JAKs) associated with cytokine stimulated receptors [31]. The most well-known activator is interleukin 6 (IL-6). However, other members of the IL-6 family are also able to activate STAT3, including IL-10 [32], IL-11 [33], Ciliary Neurotrophic Factor (CNTF) [34], Leukemia Inhibitory Factor (LIF) [35] and Oncostatin [36]. Phosphorylation of Tyr705 is also rapidly increased by receptor tyrosine kinases including Epidermal Growth Factor Receptor (EGFR) [37], Vascular Endothelial Growth Factor Receptor (VEGFR) [38], Platelet-derived Growth Factor Receptor (PDGFR) [39] and Insulin-like Growth Factor 1 Receptor (IGFR) $[39,40]$ as well as by non-receptor tyrosine kinases like Src-family kinases (Src, Hck, Lyn, Fyn, Fgr) [41], Bcr-Abl [42] and Bone Marrow X-linked non-receptor tyrosine kinase (BMX) [43]. Recent studies also identified Toll-like receptors as Tyr705 activators [44, 45]. Moreover, Tyr705 can be indirectly activated by G-protein coupled receptors such as Sphingosine-1-phosphate Receptor 1 (S1PR1) [46], BV8 [47] or angiotensin II [48]. Engagement of cadherins was also shown to activate STAT3 through up-regulation of IL-6 family cytokines [49].

In addition, STAT3 is phosphorylated at serine 727 (Ser727) by members of the Mitogen-activated Protein Kinases (MAPK) like p38MAPK [50] or Extracellular Signal Regulated Kinases (ERK) [51], by c-Jun N-terminal Kinase families (JNK) [52] and by Protein Kinase C (PKC) [53]. The Mammalian Target of Rapamycin (mTOR) may also

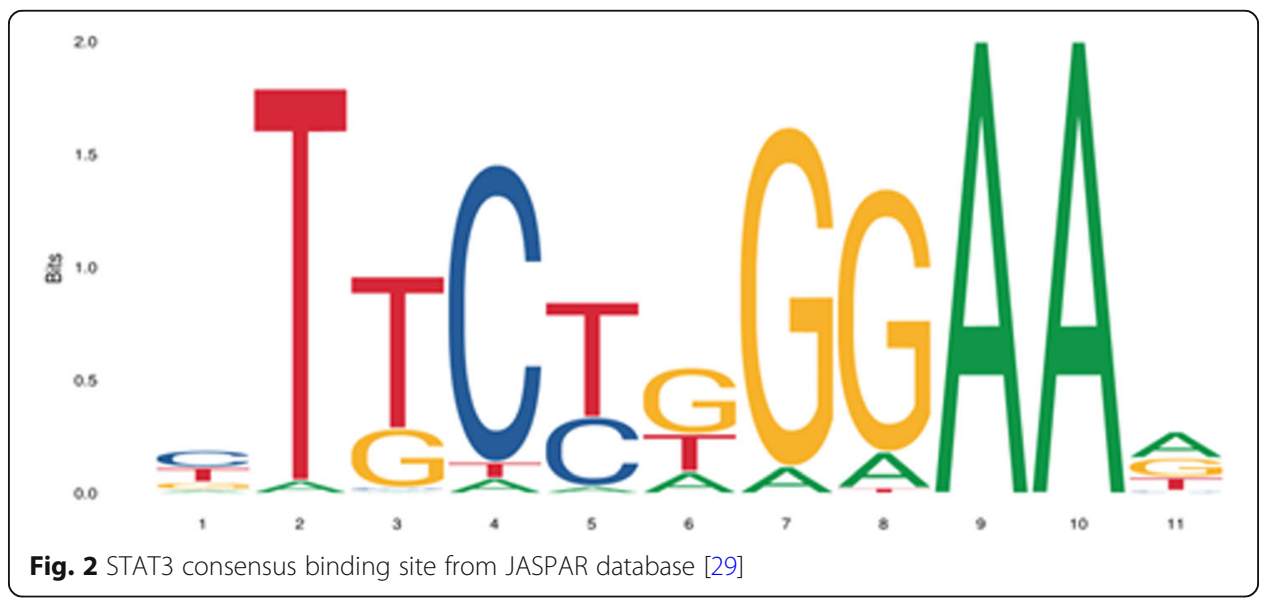


phosphorylate STAT3 at Ser727 [54]. It was generally believed that phosphorylation of Tyr705 is necessary for STAT3 activation, whereas Ser727 phosphorylation is required for its maximum activity, presumably by recruiting transcriptional co-factors $[55,56]$. However, Ser727 phosphorylation can also reduce p-Tyr705 [57] and recent studies have suggested that STAT3 can be activated through Ser727 phosphorylation in the absence of Tyr705 phosphorylation. For example, a correlation was found between Ser727 phosphorylation in the absence of Tyr705 phosphorylation and survival of neuronal stem cells [58]. Moreover, constitutive activation of Ser727 is essential for the survival of primary human in vitro differentiated macrophages [59] and drives prostate carcinogenesis independently of Tyr705 phosphorylation [60]. Above that, STAT3 is constitutively phosphorylated at Ser727 while not at Tyr705 in chronic lymphocytic leukemia [61, 62]. In addition, STAT3 can localize in mitochondria, where is serine phosphorylated and regulates mitochondrial functions independently from its transcriptional activity [63, 64].

Unphosphorylated STAT3 (U-STAT3) may also activate gene transcription. STAT3 nuclear import is independent of tyrosine phosphorylation and is mediated by importin- $\alpha 3$ [65], Ran and importin-beta1 [66]. U-STAT3 dimerization is influenced by disulfide bonds between cysteines [67] and dimers bind to the same GAS DNA-binding site as phosphorylated STAT3 but also bind AT-rich DNA structures to influence chromatin organization [68]. Moreover, U-STAT3 core protein (lacking the N-terminal domain) binds to target $d s$ DNA [69]. Several genes (Cdc2, Cyclin B, Mras, E2f-1, Rantes) do not respond directly to phosphorylated STAT3 but are activated in the late phases of IL-6 driven responses when there is an accumulation of U-STAT3 [70]. Some STAT3-responsive genes have kappa B elements, and these genes are activated by a transcription factor complex formed when U-STAT3 binds to unphosphorylated Nuclear Factor Kappa B (NF-kB) [71].

STAT3 dimerization is also positively regulated by reversible acetylation of residue Lys685 by its co-activator p300/CREB-binding protein [72-74] and by tri-methylation of Lys180 [75].

\section{Negative regulation of STAT3}

Dephosphorylation of STAT3 by protein phosphatases plays a major role in regulating STAT3. Multiple protein tyrosine phosphatases such as MEG2 [76], CD45 [77], Srchomology Region 2 Domain-containing Phosphatase 1/2 (SHP1/2) or T-cell Protein Tyrosine Phosphatases (TC-PTP) [78] have been shown to dephosphorylate Tyr705 of STAT3. STAT3 Ser727 can be dephosphorylated by Protein Phosphatase 1 (PP1) [79] or Dual Specificity Protein Phosphatase 2 (DUSP2) [80].

The SOCS proteins negatively regulate JAK/STAT3 signaling through three different mechanisms; inhibition or targeting JAKs for degradation by the proteasome; shielding the STAT3 binding sites on the cytokine receptor; or removing target proteins via ubiquitination and proteasomal degradation [81]. SOCS3 is known to negatively regulate STAT3 activity [82]. PIAS proteins participate in negative regulation during later phases of signaling. They are endogenous inhibitors of STATs that act as E3-type small ubiquitin-like modifier ligases. PIAS3 is known to block the DNA-binding activity of STAT3 and inhibits STAT3-mediated gene activation [83, 84]. Other posttranslational modifications such as methylation of Lys140 can also negatively regulate STAT3 activity [85]. 


\section{STAT3 regulation by miRNAs}

Several studies have indicated that miRNAs are critical regulators of STAT3. A number of miRNAs have been identified that affect STAT3 signaling in various types of cancers (reviewed in [86]). Moreover, some miRNAs have been shown to play a role in regulating stem cells and cancer stem cell properties. $m i R-124$ was found to directly target STAT3 mRNA to regulate cardiomyocyte differentiation of bone marrow-derived mesenchymal stem cells [87]. $m i R-1181$ inhibits stem cell-like phenotypes and suppresses STAT3 in human pancreatic cancer [88], whilst miR-7 indirectly inhibits STAT3 and thereby decreases the number of breast cancer stem cells [89].

To summarize the data above, it is evident that STAT3 expression and activation are regulated by multiple signals and they play a role in many signaling pathways. This enables STAT3 to be a flexible and adaptable regulator of cell function in different types of cells under different conditions and regulate gene expression directly or indirectly through other transcription factors [90]. An overview of STAT3 regulation is shown in Fig. 3. This review will now focus on STAT3's involvement in signaling pathways regulating stem cells and cancer stem cells.

\section{STAT3 and stem cells}

Stem cells are defined by their ability to self-renew and to generate progenitor cells that can subsequently divide and differentiate into the different types of cells of a particular tissue [91]. There are two main types of naturally occurring stem cells: embryonic stem

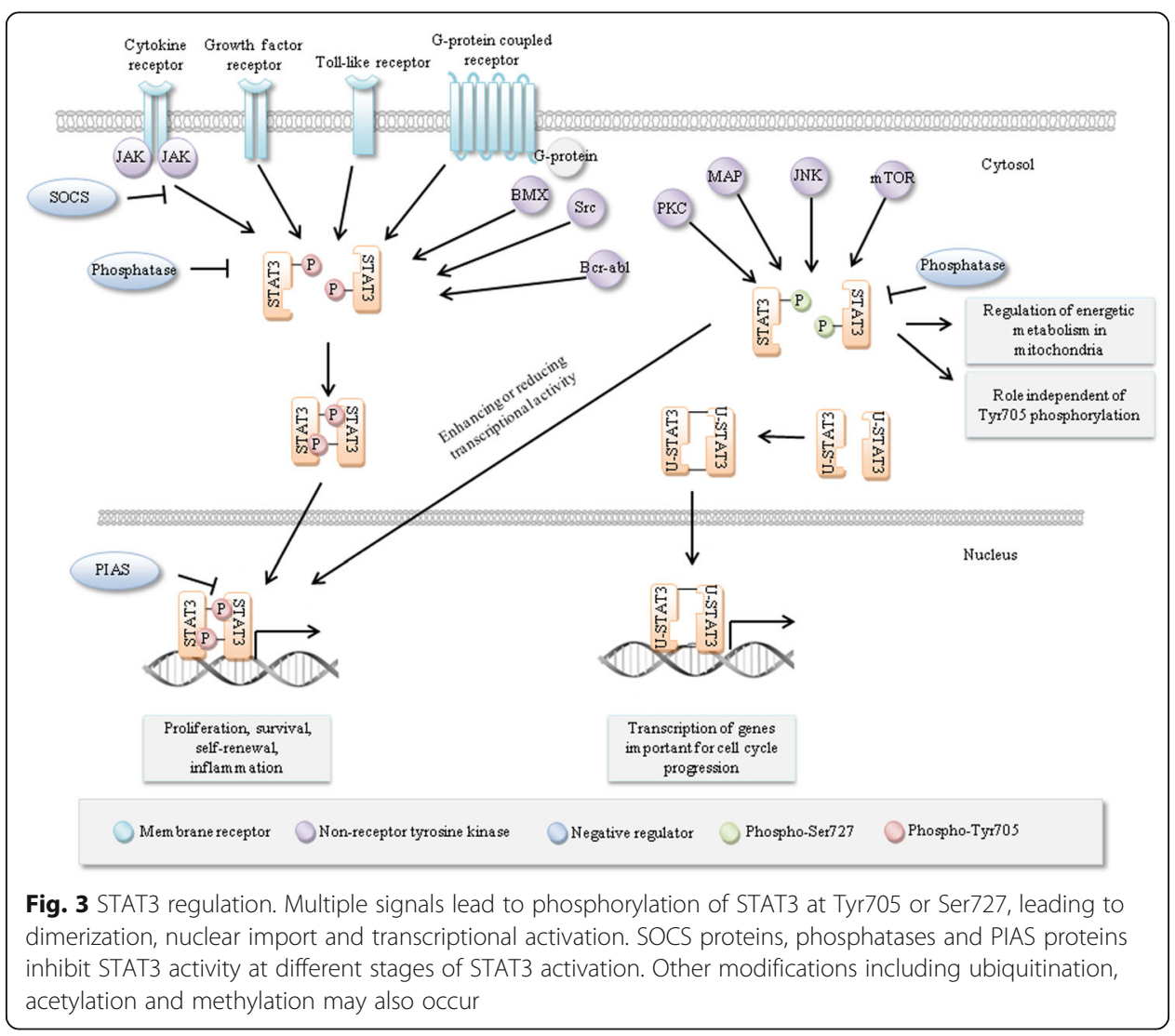


cells, which are isolated from the inner cell mass of blastocysts, and adult stem cells, which are found in various tissues. Embryonic stem cells are considered to be totipotent and can give rise to all cell types in the organism whereas adult stem cells are pluripotent, showing lineage restriction according to the particular tissue in which they reside. The other type of stem cells are induced pluripotent stem cells (iPSCs) that can be generated from adult cells [92].

Mouse stem cells

Mouse embryonic stem cells (mESCs)

LIF and its close relatives (IL-6) family are known to maintain pluripotency of mESCs [93]. The effect of LIF on JAK/STAT3 signaling is mediated through the LIF receptor (LIFR) which consists of two subunits: gp130, which is common for all types of cytokine receptors, and LIF receptor beta (LIFR $\beta)$. LIF induces heterodimerization and phosphorylation of these subunits [94] leading to rapid phosphorylation of intracellular non-receptor JAKs that phosphorylate STAT3 on tyrosine residues [95]. This phosphorylation is responsible for STAT3 activation necessary for self-renewal of mESCs. It seems that activated STAT3 is sufficient to maintain the undifferentiated state of mESCs. However, there is a threshold, and mESC lines with lower expression of constitutively active STAT3 are not able to fully inhibit differentiation [96]. STAT3 activation in mESCs leads to expression of genes that are known regulators of pluripotency, such as $M y c$ or Bcl3 $[97,98]$ and activated STAT3 is known to cooperate with Nanog, another key component of pluripotency [99]. Thus, STAT3 plays a major role in regulating mESCs fate. The regulation is possibly enabled by existence of the two different phosphorylation sites Tyr705 and Ser727, whose modification could switch between self-renewal and differentiation [100].

\section{Mouse adult stem cells}

Gu et al. [101] demonstrated that suppression of STAT3 promotes neurogenesis and inhibits astrogliogenesis in neural stem cells. Moreover, Kamakura et al. [102] showed a crosstalk between differentiation pathways where STAT3 is activated in the presence of active Notch as well as the Notch effectors Hes1 and Hes5. However, STAT3 plays a role not only during postnatal development of the mouse neocortex, the interaction between the JAK/STAT3 and Notch ligand Delta-like1-Notch signaling pathways plays an essential role in maintaining neural precursors during early neocortical development [103]. STAT3 also seems to be an important regulator of hematopoietic regeneration [104], self-renewal of adult muscle satellite cells during injury-induced muscle regeneration [105], regeneration of airway ciliated cells from basal stem cells [106], adipogenesis [107], differentiation of multiciliated [106] and hair cells [108] in mouse models. Furthermore, STAT3 is required to maintain the full differentiation potential of mouse mammary stem cells and the proliferative potential of mammary luminal progenitors [109].

\section{Human stem cells}

\section{Human embryonic stem cells ( $h E S C s$ )}

As mentioned above, stemmness of mES cells is maintained through a signaling pathway including the IL-6 family of cytokines, JAKs and STAT3. However, this pathway has little effect on hESCs [93]. Human LIF can induce STAT3 phosphorylation and 
nuclear transportation through gp130/LIFR $\beta$, but is unable to maintain the pluripotent state of hESCs [110]. However, Yang et al. [111] showed that increased STAT3 activation is sufficient to convert epiblast-derived stem cells to naive pluripotency and Chen et al. [112] observed that temporarily increasing STAT3 activity is sufficient to reprogram hESCs to naive-like pluripotent cells. Hence, STAT3 activation is a limiting factor in somatic cell reprogramming.

\section{Human adult stem cells}

There are numerous studies that have investigated the role of STAT3 in human mesenchymal stem cells (hMSCs). hMSCs are a heterogeneous population of non-hematopoietic precursor cells predominantly found in the bone marrow. Matsui et al. [113] demonstrated that hMSCs protect against obstruction-induced renal fibrosis by decreasing STAT3 activation and STAT3-dependent Matrix Metallopeptidase 9 production. Interesting to note is the interaction of hMSCs with cancer cells via cytokine networks. Hsu et al. [114] showed that the IL-6/JAK/STAT3 pathway could be activated by hMSCs when they are co-cultured with lung cancer cells to enhance lung cancer initiation. Rattigan et al. [115] illustrated that IL-6, which is produced and secreted at high levels by breast cancer cells in response to hypoxia, regulates hMSC migration towards cancer cells. IL-6 binds to its receptor on hMSCs, leading to STAT3 activation to promote hMSCs migration and survival.

\section{STAT3, cancer and cancer stem cells}

STAT3 is constitutively activated in many types of human solid tumors and hematological malignancies [116]. For example, STAT3 activation occurs in more than $40 \%$ of breast cancers, most often in the triple negative subtype that lack estrogen receptor, progesterone receptor and Human Epidermal Growth Factor 2 (HER2) amplification [5, 117]. However, the STAT3 gene is very rarely altered in human malignancies by copy number variation, point mutation or methylation and rarely by gene expression according to the Catalogue of Somatic Mutations in Cancer (COSMIC) database (Fig. 4) [118].

In the absence of genetic alterations, constitutive activation occurs through upstream factors such as growth factor or cytokine production acting through paracrine or autocrine pathways; amplification or activating mutations in related receptors; mutations in kinase signaling cascade pathway genes; and/or the loss of negative regulators of STAT3 activity. Constitutive activation of STAT3 is predictive of poor prognosis in many types of cancer [119-121] and although STAT3 is only rarely altered by gene expression changes, mRNA levels show a similar trend. Using publicly available array profiling data, we could show here that in triple negative breast cancer, which is a representative cancer with constitutive STAT3 activation, higher mRNA levels show a trend for worse relapse-free survival (RFS). Conversely, in $\mathrm{ER}^{+}$breast cancer where the activation of STAT3 is low, high STAT3 mRNA levels indicate a better RFS probability (Fig. 5) [122].

There is an opposite trend also between the main groups in ovarian and lung cancer. Low STAT3 mRNA levels indicate better progression-free survival (PFS) in serous ovarian cancer, whereas high levels point to better PFS in endometrioid ovarian cancer. Low STAT3 mRNA levels in lung adenocarcinoma and oppositely high levels in squamous cell lung cancer indicate better first progression (FP) probability. In gastric cancer, high STAT3 mRNA levels indicate worse FP probability. For these analyses we used KM-plotter cited in [123] (Table 1). 


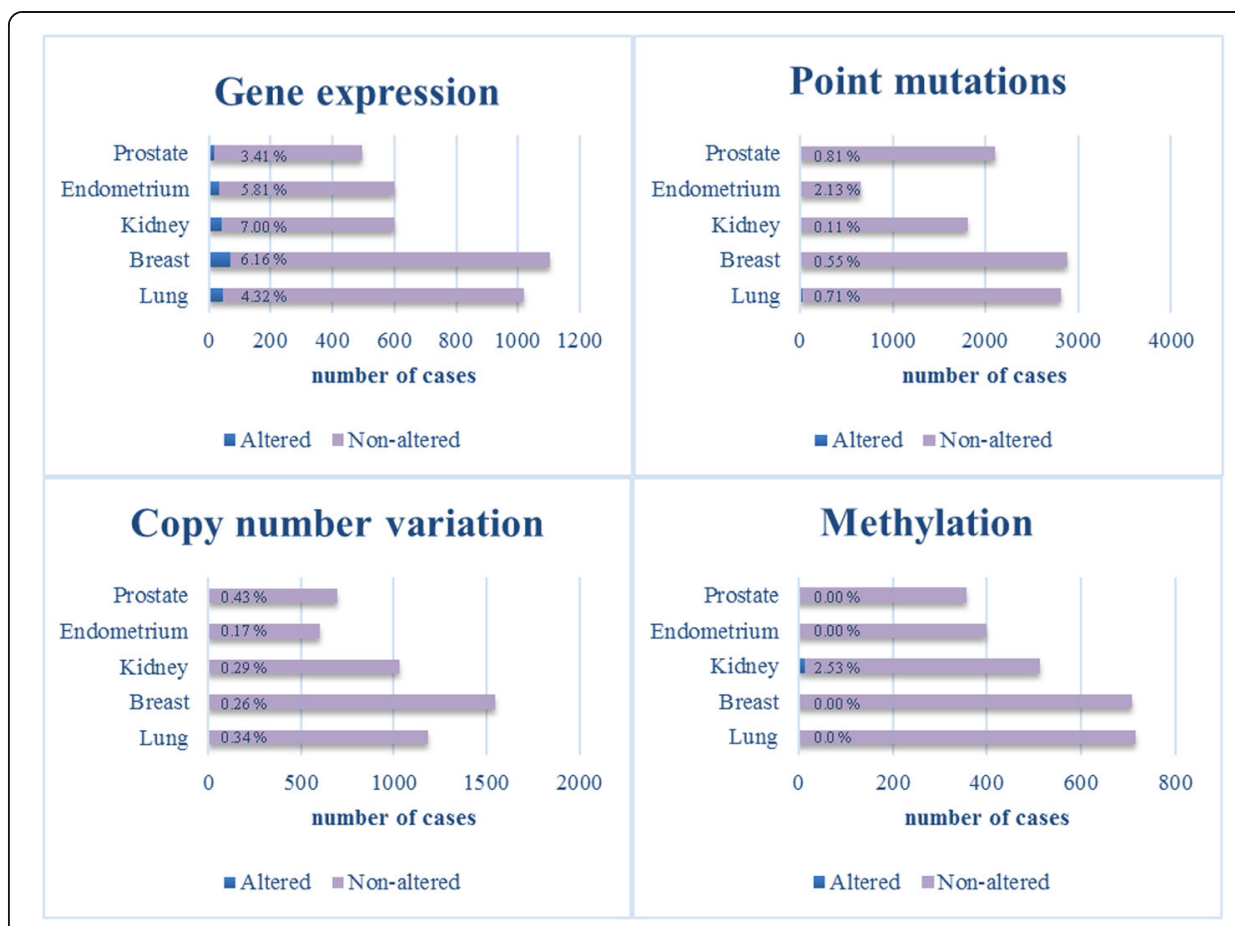

Fig. 4 STAT3 mutational status. The table showing the distribution of mutations across the primary tissue types that are curated by COSMIC database was used as template. Only cancer types with all mutation types included were chosen for this picture [118]

Patient outcomes in relation to STAT3 mRNA expression are described by logrank $p$ value. Affymetrix ID for STAT3 was 225289_at. Relapse-free survival (RFS) was analysed in breast cancer, progression-free survival (PFS) in ovarian cancer and firstprogression (FP) in lung and gastric cancers. JetSet best probe set and auto select best cut-off were used for analysis from Kaplan-Meier plot [123]. Upward arrows indicate that

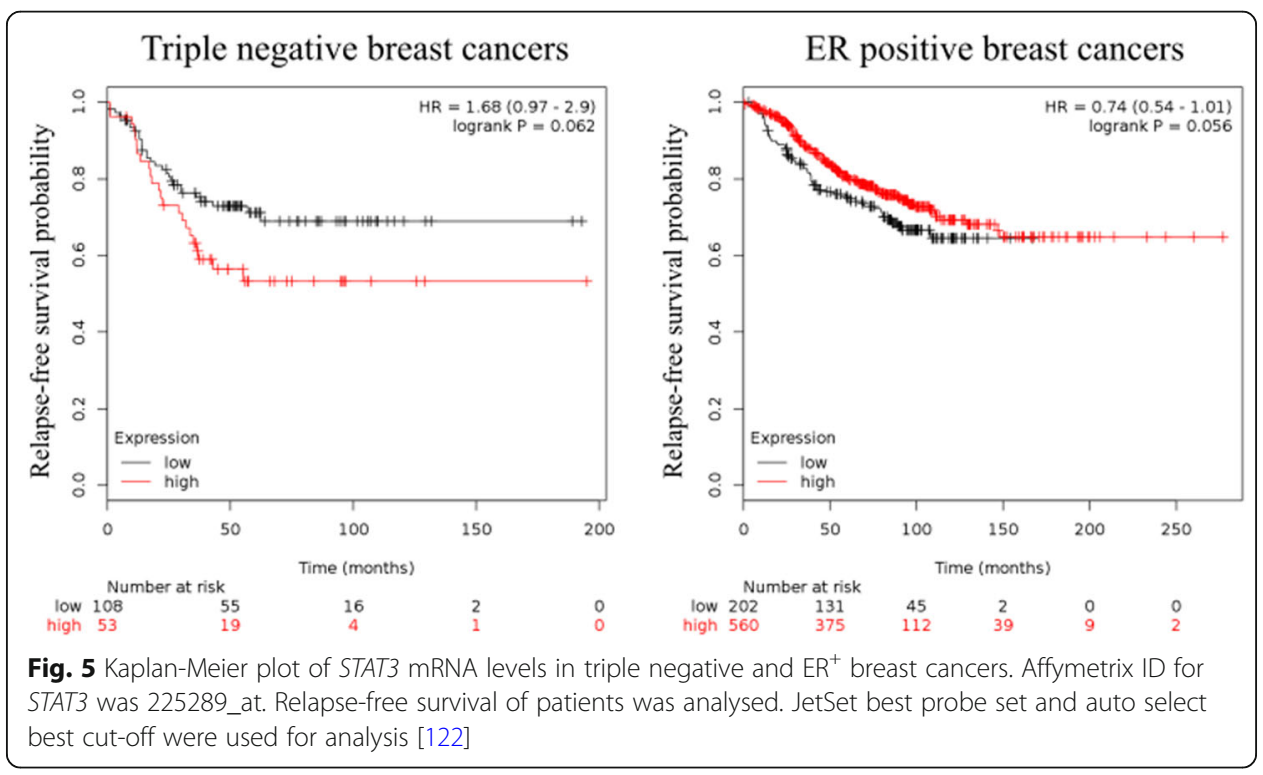


Table 1 Patient outcomes in relation to STAT3 mRNA expression in breast, ovarian, lung and gastric cancers

\begin{tabular}{llll}
\hline Breast cancer & All types $(n=1764)$ & Triple negative $(n=161)$ & ER positive $(n=762)$ \\
\hline RFS probability & $0.0530 \downarrow$ & $0.0620 \downarrow$ & $0.0560 \uparrow$ \\
Ovarian cancer & All types $(n=614)$ & Serous $(n=483)$ & Endometrioid ( $n=44)$ \\
PFS probability & $0.0160 \downarrow$ & $0.0150 \downarrow$ & $0.0720 \uparrow$ \\
Lung cancer & All types $(n=596)$ & Adenocarcinoma $(n=443)$ & Squamous cell ( $n=141)$ \\
FP probability & $0.020 \downarrow$ & $0.0058 \downarrow$ & $0.0002 \uparrow$ \\
Gastric cancer & All types $(n=522)$ & & \\
FP probability & $0.3300 \uparrow$ & & \\
\hline
\end{tabular}

higher STAT3 levels correlate with improved survival; downward arrows indicate that lower STAT3 levels associate with improved survival.

As mentioned at the beginning, STAT3 is also important in tumor biology for its ability to promote cancer through regulating cancer stem cell activities. It is widely accepted that tumors contain a sub-population of cells that share properties with normal tissue stem cells, called cancer stem cells or cancer stem-like cells (CSCs) [124-128]. However, the CSC theory remains controversial because of the variety of differences between CSCs and normal stem cells. As stem cells, CSCs have the ability to selfrenew, however while normal stem cells are able to differentiate into multiple distinct cell types, most CSCs differentiate into only a single cell type, the cells which form the bulk of the tumor. However, an evidence for multilineage differentiation potential of CSCs was reported in colon carcinomas and leukemia. Another difference is that while the phenotypes of normal stem cells seem to be fixed, the phenotypes of CSCs vary from one tumor to another tumor of the same molecular/pathological type, most likely because they are affected by the abnormalities resulting from the process of neoplastic transformation [127]. CSC identification and understanding of their biology could have critical clinical relevance, because CSCs are uniquely able to reform the tumor and exhibit enhanced resistance to cancer treatments [124-128]. Notably, as mentioned above, STAT3 is often constitutively activated in triple negative breast cancers and these cancers display a profile of cell surface markers that is similar to that of breast CSCs $[117,126,129]$. Below, we summarize the evidence for the role of STAT3 in CSCs properties in the common human malignancies.

STAT3 was reported to have an essential role in maintaining the expression of genes that are important for stem cell phenotype and are used as markers of CSCs. Many putative CSC markers have been identified, the most commonly used are expression of transmembrane glycoproteins CD24, CD34, CD38, CD44, CD90 and CD133, together with Aldehyde Dehydrogenase (ALDH), the ability to form spheroids in suspension in vitro and the ability to exclude cell permeable dyes such as Hoechst33342 for side population assessment [127]. The STAT3 pathway is preferentially active in subpopulations of cells enriched for CSC markers and its inhibition decreases cell viability and tumorsphere formation. On the other hand, several proteins that stimulate cell growth and proliferation reduce its activity [117, 130, 131]. Importantly, STAT3 can form a complex with internalized CD44 and acetyltransferase p300, inducing STAT3 acetylation at Lys685, dimer formation and translocation to the nucleus where it binds to the promoters of genes including cell cycle regulators cyclin D1 [47] or Myc and Twist1 
[132]. Furthermore, STAT3 was found to physically interact with CD44 and NF-kB and activate the catalytic subunit of telomerase to prolong proliferative potential [133]. Moreover, activated STAT3 can increase CD133 expression through functional cooperation with NF- $\kappa B$ and Hypoxia Inducible Factor 1 Alpha (HIF-1 $\alpha$ ) [134].

Nowadays, epithelial-mesenchymal transition (EMT) and tumor microenvironments are highly discussed topics in the context of CSCs. There is increasing evidence pointing to plasticity between CSCs and their more differentiated derivatives. It is considered that whereas CSCs can differentiate into non-CSCs, the reverse process is also possible via EMT, which is a transdifferentiation program required for tissue morphogenesis during embryonic development $[135,136]$. Over and above that, several studies reported direct links between EMT and gain of CSC properties [137, 138]. EMT and CSC formation is a dynamic process triggered by multiple shared signaling pathways, such as Transforming Growth Factor $\beta$ (TGF- $\beta$ ), Wnt/ $\beta$-catenin, Hedgehog, Notch, NF-кB and others $[139,140]$.

It was reported that hepatocellular carcinoma could arise from IL-6/STAT3 driven transformed stem cells with inactivated TGF- $\beta$ signaling and that human hepatocellular cancer cells expressing STAT3 and the putative stem cell markers Octamer-binding Transcription Factor 4 (OCT4) and Nanog lost pro-differentiation proteins TGF- $\beta$ receptor type II and Embryonic Liver Fodrin [141]. In addition to this role in hepatocellular cancer, STAT3 activation plays a role in EMT induction in different types of tumors. STAT3 can be activated by IL- 6 dependent or independent mechanisms such as a non-canonical Frizzled 2 pathway [142] or TGF- $\beta /$ LIF [143]. Moreover, induction of EMT after STAT3 activation and expansion of the CSC population were observed in relation to resistance to cisplatin or trastuzumab $[144,145]$. The mechanisms of trastuzumab resistance, which is a HER2-targeting antibody used to treat HER2 ${ }^{+}$breast cancer, are well-documented. Inactivation of Phosphatase and Tensin Homolog (PTEN) leads to increased resistance to this drug and it seems that STAT3 is a negative regulator of PTEN among trastuzumab-resistant cells [146, 147]. An IL-6 loop was found, where IL-6 activates the AKT, STAT3 and NF- $\kappa B$ pathways while suppressing PTEN expression [146]. Recently, it was found that trastuzumab resistance in this type of cancer is promoted through activation of a STAT3/HIF- $1 \alpha /$ Hes 1 axis via downregulation of PTEN [147].

STAT3 activation was observed also in HER2 negative breast cancer, where activation of STAT3 also correlates with CSC properties. The STAT3 pathway is positively regulated by mTOR signaling in this context, whereas PTEN serves as a negative regulator of both STAT3 and mTOR [148]. Moreover, PTEN appears to function as a crucial inhibitor of glioblastoma stem cells through mediating cooperative perturbation of AKT and STAT3 signals [149].

Furthermore, STAT3 is a critical transcription factor in angiogenesis; it participates in expression and protein stability of HIF- $1 \alpha$ and regulates or is itself regulated by VEGF. This involvement was also shown to play a role in maintaining the self-renewal properties of CSCs [38]. Interestingly, VEGF-mediated angiogenesis was reported to link EMT-induced cancer stemness to tumor initiation [150].

STAT3 is also involved in the regulation of NF- $\mathrm{kB}$ signaling in tumor cells and in non-transformed stromal cells in the tumor microenvironment. STAT3 physically interacts and functionally cooperates with NF- $\mathrm{KB}$ in tumor cells and also in tumor-associated 
immune cells $[7,47,134]$. Among tumor-associated immune cells, tumor-associated macrophages were found to promote CSC-like phenotypes through Milk Fat Globule-EGF Factor 8 (MGF-E8)/STAT3 and Sonic Hedgehog pathways, or through EGFR/STAT3/ Sox2 [151, 152]. Moreover, it was also shown that mast cells modulate proliferation, migration and stemness through down-regulation of GSK3 $\beta$ and inhibition of STAT3 activation [153].

STAT3 can be activated and thereby contribute to CSCs properties by the BMX [43] and Ras homolog family member C [154] and it can be activated also epigenetically by the histone-lysine N-methyltransferase Enhancer of Zeste Homolog 2 (EZH2) [75].

Taking the above observations together, the roles STAT3 in promoting and maintaining CSC properties are highly complex. STAT3 directly interacts with transmembrane glycoproteins which are expressed by normal stem cells and are widely used as markers to identify and isolate CSCs. STAT3 is involved in pathways that are connected with EMT, which is one of the major proposed mechanisms of generating CSCs. Moreover, it plays a critical role in angiogenesis and participates in regulating the tumor microenvironment that provides signals for differentiation or proliferation especially through its involvement in inflammatory NF- $\kappa$ B pathway. In addition, feedback activation of STAT3 may play a prominent role in mediating drug resistance to a broad spectrum of targeted cancer therapies and chemotherapies [155]. Although it seems to be an ideal target for anti-cancer therapy, effective approaches to inhibit STAT3 are still missing. This lack is caused presumably because of the complexity of STAT3's biology in normal as well as cancer cells and also because it lacks enzymatic activity, making it a challenging target [86]. Inhibitors of STAT3 which are currently tested are reviewed in [155], although no inhibitor that directly targets STAT3 has yet been approved by the US Food and Drug Administration for clinical use. However, several tyrosine kinase inhibitors are in the clinic such as sorafenib and sunitinib that can inhibit STAT3 signaling indirectly, leading to tumor cell cycle arrest and apoptosis [156, 157].

As was mentioned in the beginning, there is increasing evidence that STAT3 activation and p63 expression are connected; hence their relationship will be briefly discussed in the following part of this review.

\section{The connections between STAT3 and p63}

p63 is a member of the p53 family of transcription factors that consists of p53, p63 and p73 proteins. All family members have important functions in tumorigenesis and morphogenesis and share the same domain organization including an N-terminal transcription activation domain (TAD), a DNA binding domain (DBD) and a C-terminal oligomerization domain (OD). They act as tetramers and due to their partial homology in the oligomerization domain they may form heterotetramers. They also have highly homologous DNA binding domains, indicating that they are able to bind to the other family members target genes. The TP63 gene is localized on chromosome 3 and gives rise to multiple isoforms due to differential promoter selection (full-length TA and Nterminal truncated $\triangle \mathrm{Np} 63)$ and alternative splicing of the 3'end of the mRNA $(\alpha, \beta, \gamma$, $\delta, \varepsilon)[158]$ (Fig. 6). $\Delta$ Np63 isoforms lack the $\mathrm{N}$-terminal transactivation domain, hence they are able to antagonize full-length isoforms of p63 and also other p53 family members and act like dominant negative transcription inhibitors. Nevertheless, they also 


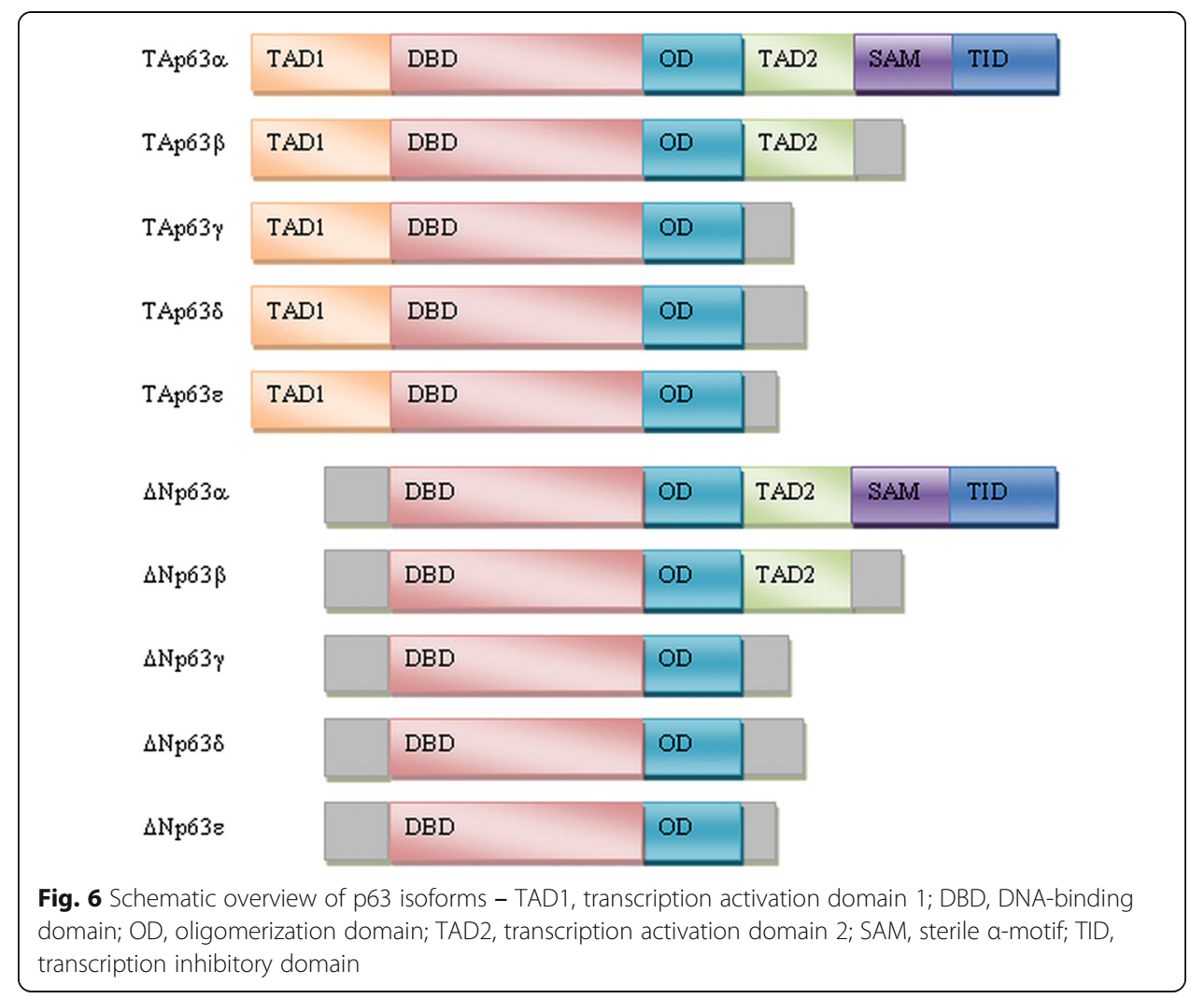

have transactivation activity due to the presence of an alternative TAD [158, 159]. Among C-terminal isoforms, p63 $\alpha$ isoforms have a sterile alpha motif (SAM) that is known to be involved in protein-protein interactions and they have a transcription inhibitory domain (TID), which inhibits its transcriptional activity [160, 161].

p63 is well known for its role in epidermal development. The importance of this protein during this process was established using p63 null mice. Those mice showed a complete lack of stratified squamous epithelia and their derivatives or they had stratified but disrupted epidermis depending on the used model. They also had absent or truncated limbs and craniofacial abnormalities $[162,163]$. The predominant isoform in epithelial tissues is $\Delta \mathrm{Np} 63 \alpha$ which is highly expressed in the basal cells of stratified and glandular epithelia, including epidermis, and its levels decrease with cellular differentiation. Oppositely, TAp63 positive cells are located suprabasally in stratified epithelia, indicating a switch between isoforms during differentiation $[1,2,9] . \Delta N p 63$ protein expression is restricted to other basal cells including those in breast, prostate, bladder and colorectum. Thus, it is widely used as a marker for this type of cells [1, 11, 12, 164]. Interestingly, activated STAT3 plays a role in promoting the regeneration of airway ciliated cells from basal stem cells [106] and is also involved in malignant transformation of foregut basal progenitor cells [165]. Furthermore, it was shown using ChIP-Seq analysis that p63 co-operates with STAT3 in human keratinocytes [166].

p63's role in tumorigenesis is complex, also because it seems that TAp63 and $\triangle \mathrm{Np} 63$ isoforms play opposite roles in this process. Like STAT3, TP63 is rarely mutated in human cancer, but p63 activity is often increased. One mechanism for increased activity of p63 is gene amplification, and many tumors with amplification show increased p63 
expression [9]. $\Delta \mathrm{Np} 63$ is supposed to behave as oncoprotein and is up-regulated in squamous cell carcinomas [11, 167] and triple negative basal-like breast tumors [4] amongst other tumor types. It also plays roles in a variety of pathways that are implicated in CSC properties, reviewed in [8]. In addition, $\triangle \mathrm{Np} 63$ increases the expression of Wnt receptor Frizzled 7 thereby enhancing Wnt signaling which leads to promotion of normal mammary stem cell activity and tumor initiating activity in the basal-like subtype of breast cancer [168]. Further, Memmi et al. [13] showed a positive modulation of Hedgehog signaling pathway by $\triangle \mathrm{Np} 63$ to maintain selfrenewal potential of mammary CSCs. On the other hand, TAp63 shares the abilities of the "guardian of the genome" p53 to induce cell cycle arrest and apoptosis and TAp63 may thus act as tumor suppressor. However, there are also reports that it could behave as oncogene. For example, TAp63 is the predominant isoform expressed in hematological malignancies, and it was shown that TAp63 overexpression leads to increased tumor progression of head and neck squamous cell carcinoma. It is also expressed in colon carcinoma [1, 169].

STAT3 is often given in connection with $\Delta$ Np63. Both $\Delta$ Np63 $[3,4,13,129]$ and STAT3 [117, 170, 171] were suggested as CSC markers and are associated with triple negative breast tumors that show more CSC markers than non-triple negative. STAT3 is also frequently constitutively activated in squamous cell carcinomas [121, $172]$, where $\Delta \mathrm{Np} 63$ is often over-expressed. Furthermore, they were both reported as master regulators of mammary cancer stem cell maintenance [13, 173]. Additionally, the dual-regulatory effect $\triangle \mathrm{Np} 63$ on its own promoter is dependent on STAT3 activation and it was confirmed that STAT3 binds to the $\Delta$ Np63 promoter $[159,174]$ and regulates proliferation and differentiation of rabbit limbal epithelial cells via a $\Delta \mathrm{Np} 63$ mechanisms [175]. There is a possible mechanism involving EGFR signaling pathway that could regulate STAT3 and $\triangle \mathrm{Np} 63$ activation and expression. It was observed that $\triangle \mathrm{Np} 63$ expression is regulated by EGFR/STAT3 axis and this is crucial for proliferation of CSCs [176]. Oppositely, we found that $\triangle \mathrm{Np63}$ activates EGFR signaling in triple negative breast cancer [4]. Moreover, STAT3 is activated by mTOR and thereby p63 expression is induced and in turn activates Notch signaling through stimulation of Jag1 gene expression and impedes murine and human cell differentiation [177]. Besides the above-mentioned evidence that STAT3 and $\triangle \mathrm{Np63}$ are closely linked, $\triangle \mathrm{Np} 63$ is also involved in inflammatory NF-кB pathway [178, 179], angiogenesis through VEGF [180], and EMT. There are numerous papers about $\triangle \mathrm{Np} 63$ involvement in signaling pathways connected with EMT (reviewed in [181]). Some papers claim that $\Delta \mathrm{Np} 63$ promotes EMT and reduces the opposite process of mesenchymal-epithelial transition (MET), whereas others provide evidence for an opposite role of $\Delta \mathrm{Np} 63$. To help with explaining contradictory reports could serve a paper [182] where they describe that p63 can trigger the Notch signaling pathway in neighboring cells to potentially promote EMT. Interestingly, Su et al. [183] recently showed that TAp63 is crucial for the transition of mammary cancer cells to acquire characteristic of tumorinitiating cells.

Studying the relationships of p63 with STAT3 and generally the role of p63 in cancer needs careful assessment of isoforms that are being expressed. Moreover, p63 isoforms must be studied in close relationship with the other p53 family members because of the existence of the many possible interactions between p53, p63 and p73 [8]. 


\title{
Conclusion
}

STAT3 signaling is a major regulatory pathway of mouse embryonic stem cell fate and also a limiting factor in human somatic cell reprogramming and plays important roles in the maintenance and proliferation of adult stem cells. STAT3 activation occurs during many aspects of carcinogenesis, including involvement in regulating CSC properties. Together with $\triangle \mathrm{Np} 63$ it was suggested as a marker of CSCs, a major regulator of mammary CSCs maintenance and both are mostly associated with triple negative tumors. They were found to directly interact and they are both involved in several common pathways regulating CSC properties, however their relationship is still not well established and remains to be determined.

\begin{abstract}
Abbreviations
ALDH: Aldehyde Dehydrogenase; BMX: Bone Marrow X-linked non-receptor tyrosine kinase; CCD: Coiled Coil Domain; CNTF: Ciliary Neurotrophic Factor; COSMIC: Catalogue of Somatic Mutations in Cancer; CSCs: Cancer Stem Cells; DBD: DNA-binding Domain; DUSP2: Dual Specificity Protein Phosphatase 2; EGFR: Epidermal Growth Factor Receptor; EMT: Epithelial-mesenchymal Transition; ER: Estrogen Receptor; ERK: Extracellular Signal Regulated Kinase;

EZH2: Enhancer of Zeste Homolog 2; FP: First Progression; GAS: Interferon-Gamma-Activated Sequence; HER2: Human Epidermal Growth Factor Receptor 2; hESCs: Human Embryonic Stem Cells; HIF-1a: Hypoxia Inducible Factor Alpha; hMSCS: Human Mesenchymal Stem Cells; IGFR: Insulin-like Growth Factor 1 Receptor; IL: Interleukin; iPSCs: Induced Pluripotent Stem Cells; JAK: Janus Kinase; JNK: c-Jun N-terminal Kinase; LD: Linker Domain; LIF: Leukemia Inhibitory Factor; LIFR: Leukemia Inhibitory Factor Receptor; LIFRß: Leukemia Inhibitory Factor Receptor Beta; MAPK: Mitogen Activated Protein Kinase; mESCs: Mouse Embryonic Stem Cells; MET: Mesenchymal-epithelial Transition; MGF-E8: Milk Fat Globule-EGF Factor 8; mTOR: Mammalian Target of Rapamycin; NF-kB: Nuclear Factor Kappa B; NTD: NH2-terminal Domain; OCT4: Octamer-binding Transcription Factor 4; OD: Oligomerization Domain; PDGFR: Platelet-derived Growth Factor Receptor; PFS: Progression-free Survival; PIAS: Protein Inhibitors of Activated STAT; PKC: Protein Kinase C; PP1: Protein Phosphatase 1; PTEN: Phosphatase and Tensin Homolog; RFS: Relapse-free Survival; S1PR1: Sphingosine-1phosphate Receptor 1; SAM: Sterile Alpha Motif; SH2: Src-homology 2; SHP1/2: Src-homology Region 2 Domaincontaining Phosphatase 1 and Src-homology Region 2 Domain-containing Phosphatase 2; SOCS: Suppressors of Cytokine Signaling; STAT: Signal Transducer and Activator of Transcription; TAD: Transcription Activation Domain; TCPTP: T-cell Protein Tyrosine Phosphatase; TGF- $\beta$ : Transforming Growth Factor Beta; TID: Transcription Inhibitory Domain; U-STAT3: Unphosphorylated STAT3; VEGFR: Vascular Endothelial Growth Factor Receptor
\end{abstract}

\section{Acknowledgements}

Not applicable.

Funding

The work was supported by the project MEYS - NPS I - LO1413, by the Czech Science Foundation (P206/12/G151) and by MH CZ - DRO (MMCl, 00209805). MG is Brno Ph.D. Talent Scholarship holder - Funded by the Brno City Municipality.

Availability of data and materials

Not applicable.

\section{Authors' contributions}

MG reviewed the literature and wrote the manuscript. PC and BV revised the manuscript. All authors read and approved the final manuscript.

Ethics approval and consent to participate

Not applicable.

Consent for publication

Not applicable.

Competing interests

The authors declare that they have no competing interests.

\section{Publisher's Note}

Springer Nature remains neutral with regard to jurisdictional claims in published maps and institutional affiliations.

Received: 15 December 2017 Accepted: 7 March 2018

Published online: 22 March 2018

\section{References}

1. Nylander K, Vojtesek B, Nenutil R, Lindgren B, Roos G, Zhanxiang W, et al. Differential expression of p63 isoforms in normal tissues and neoplastic cells. J Pathol. 2002;198:417-27. 
2. Nekulova M, Holcakova J, Nenutil R, Stratmann R, Bouchalova P, Müller P, et al. Characterization of specific p63 and p63-N-terminal isoform antibodies and their application for immunohistochemistry. Virchows Arch. 2013:463:415-25.

3. Orzol P, Nekulova M, Holcakova J, Muller P, Votesek B, Coates PJ. $\Delta$ Np63 regulates cell proliferation, differentiation, adhesion, and migration in the BL2 subtype of basal-like breast cancer. Tumour Biol. 2016;37:10133-40.

4. Holcakova J, Nekulova M, Orzol P, Nenutil R, Podhorec J, Svoboda M, et al. $\Delta$ Np63 activates EGFR signaling to induce loss of adhesion in triple-negative basal-like breast cancer cells. Breast Cancer Res Treat. 2017;163:475-84.

5. Banerjee K, Resat H. Constitutive activation of STAT3 in breast cancer cells: A review. Int J Cancer. 2016;138:2570-8

6. Carpenter RL, Lo HW. STAT3 Target Genes Relevant to Human Cancers. Cancers (Basel). 2014;6:897-925.

7. $\mathrm{Yu} \mathrm{H}$, Pardoll D, Jove R. STATs in cancer inflammation and immunity: a leading role for STAT3. Nat Rev Cancer. 2009:9:798-809.

8. Nekulova M, Holcakova J, Coates P, Vojtesek B. The role of p63 in cancer, stem cells and cancer stem cells. Cell Mol Biol Lett. 2011;16:296-327.

9. Orzol P, Holcakova J, Nekulova M, Nenutil R, Vojtesek B, Coates PJ. The diverse oncogenic and tumour suppressor roles of p63 and p73 in cancer: a review by cancer site. Histol Histopathol. 2015;30:503-21.

10. Avalle L, Camporeale A, Camperi A, Poli V. STAT3 in cancer: A double edged sword. Cytokine. 2017;98:42-50.

11. Bishop JA, Teruya-Feldstein J, Westra WH, Pelosi G, Travis WD, Rekhtman N. p40 ( $\Delta$ Np63) is superior to p63 for the diagnosis of pulmonary squamous cell carcinoma. Mod Pathol. 2012;25:405-15.

12. Pellegrini G, Dellambra E, Golisano O, Martinelli E, Fantozzi I, Bondanza S, et al. p63 identifies keratinocyte stem cells. Proc Natl Acad Sci U S A. 2001;98:3156-61.

13. Memmi EM, Sanarico AG, Giacobbe A, Peschiaroli A, Frezza V, Cicalese A, et al. p63 Sustains self-renewal of mammary cancer stem cells through regulation of Sonic Hedgehog signaling. Proc Natl Acad Sci U S A. 2015;1 12:3499-504.

14. You L, Wang Z, Li H, Shou J, Jing Z, Xie J, et al. The role of STAT3 in autophagy. Autophagy. 2015;11:729-39.

15. Caldenhoven E, van Dijk TB, Solari R, Armstrong J, Raaijmakers JA, Lammers JW, et al. STAT3beta, a splice variant of transcription factor STAT3, is a dominant negative regulator of transcription. J Biol Chem. 1996;271:13221-7.

16. The UniProt Consortium. UniProt: the universal protein knowledgebase. Nucleic Acids Res. 2017;45:D158-D69.

17. Schaefer TS, Sanders LK, Nathans D. Cooperative transcriptional activity of Jun and Stat3 beta, a short form of Stat3. Proc Natl Acad Sci U S A. 1995;92:9097-101.

18. Maritano D, Sugrue ML, Tininini S, Dewilde S, Strobl B, Fu X, et al. The STAT3 isoforms alpha and beta have unique and specific functions. Nat Immunol. 2004;5:401-9.

19. Kato T, Sakamoto E, Kutsuna H, Kimura-Eto A, Hato F, Kitagawa S. Proteolytic conversion of STAT3alpha to STAT3gamma in human neutrophils: role of granule-derived serine proteases. J Biol Chem. 2004;279:31076-80.

20. Hevehan DL, Miller WM, Papoutsakis ET. Differential expression and phosphorylation of distinct STAT3 proteins during granulocytic differentiation. Blood. 2002;99:1627-37.

21. Nishiki S, Hato F, Kamata N, Sakamoto E, Hasegawa T, Kimura-Eto A, et al. Selective activation of STAT3 in human monocytes stimulated by G-CSF: implication in inhibition of LPS-induced TNF-alpha production. Am J Physiol Cell Physiol. 2004;286:C1302-11.

22. Rush J, Moritz A, Lee KA, Guo A, Goss VL, Spek EJ, et al. Immunoaffinity profiling of tyrosine phosphorylation in cancer cells. Nat Biotechnol. 2005;23:94-101.

23. Bian Y, Song C, Cheng K, Dong M, Wang F, Huang J, et al. An enzyme assisted RP-RPLC approach for in-depth analysis of human liver phosphoproteome. J Proteomics. 2014;96:253-62.

24. Levy DE, Darnell JE. Stats: transcriptional control and biological impact. Nat Rev Mol Cell Biol. 2002;3:651-62.

25. Fagard R, Metelev V, Souissi I, Baran-Marszak F. STAT3 inhibitors for cancer therapy: Have all roads been explored? JAKSTAT. 2013;2:e22882.

26. Zhong Z, Wen Z, Darnell JE. Stat3: a STAT family member activated by tyrosine phosphorylation in response to epidermal growth factor and interleukin-6. Science. 1994;264:95-8.

27. Darnell JE, Kerr IM, Stark GR. Jak-STAT pathways and transcriptional activation in response to IFNs and other extracellular signaling proteins. Science. 1994;264:1415-21.

28. Decker T, Kovarik P, Meinke A. GAS elements: a few nucleotides with a major impact on cytokine-induced gene expression. J Interferon Cytokine Res. 1997;17:121-34.

29. Khan A, Fornes O, Stigliani A, Gheorghe M, Castro-Mondragon JA, van der Lee R, et al. JASPAR 2018: update of the open-access database of transcription factor binding profiles and its web framework. Nucleic Acids Res. 2017;

30. Khatib H, Huang W, Mikheil D, Schutzkus V, Monson RL. Effects of signal transducer and activator of transcription (STAT) genes STAT1 and STAT3 genotypic combinations on fertilization and embryonic survival rates in Holstein cattle. J Dairy Sci. 2009:92:6186-91.

31. Decker T, Kovarik P. Transcription factor activity of STAT proteins: structural requirements and regulation by phosphorylation and interacting proteins. Cell Mol Life Sci. 1999;55:1535-46.

32. Gupta M, Han JJ, Stenson M, Maurer M, Wellik L, Hu G, et al. Elevated serum IL-10 levels in diffuse large B-cell Iymphoma: a mechanism of aberrant JAK2 activation. Blood. 2012;119:2844-53.

33. Ernst M, Najdovska M, Grail D, Lundgren-May T, Buchert M, Tye H, et al. STAT3 and STAT1 mediate IL-11-dependent and inflammation-associated gastric tumorigenesis in gp130 receptor mutant mice. J Clin Invest. 2008;118:1727-38.

34. Peterson WM, Wang Q, Tzekova R, Wiegand SJ. Ciliary neurotrophic factor and stress stimuli activate the Jak-STAT pathway in retinal neurons and glia. J Neurosci. 2000;20:4081-90.

35. Kunisada K, Hirota H, Fujio Y, Matsui H, Tani Y, Yamauchi-Takihara K, et al. Activation of JAK-STAT and MAP kinases by leukemia inhibitory factor through gp130 in cardiac myocytes. Circulation. 1996;94:2626-32.

36. Yanagisawa M, Nakashima K, Taga T. STAT3-mediated astrocyte differentiation from mouse fetal neuroepithelial cells by mouse oncostatin M. Neurosci Lett. 1999;269:169-72.

37. Wang Y, van Boxel-Dezaire AH, Cheon H, Yang J, Stark GR. STAT3 activation in response to IL-6 is prolonged by the binding of IL-6 receptor to EGF receptor. Proc Natl Acad Sci U S A. 2013;110:16975-80.

38. Zhao D, Pan C, Sun J, Gilbert C, Drews-Elger K, Azzam DJ, et al. VEGF drives cancer-initiating stem cells through VEGFR-2/Stat3 signaling to upregulate Myc and Sox2. Oncogene. 2015;34:3107-19. 
39. Vignais ML, Sadowski HB, Watling D, Rogers NC, Gilman M. Platelet-derived growth factor induces phosphorylation of multiple JAK family kinases and STAT proteins. Mol Cell Biol. 1996;16:1759-69.

40. Zong CS, Chan J, Levy DE, Horvath C, Sadowski HB, Wang LH. Mechanism of STAT3 activation by insulin-like growth factor I receptor. J Biol Chem. 2000;275:15099-105.

41. Schreiner SJ, Schiavone AP, Smithgall TE. Activation of STAT3 by the Src family kinase Hck requires a functional SH3 domain. J Biol Chem. 2002;277:45680-7.

42. Coppo P, Flamant S, De Mas V, Jarrier P, Guillier M, Bonnet ML, et al. BCR-ABL activates STAT3 via JAK and MEK pathways in human cells. Br J Haematol. 2006;134:171-9.

43. Guryanova OA, Wu Q, Cheng L, Lathia JD, Huang Z, Yang J, et al. Nonreceptor tyrosine kinase BMX maintains selfrenewal and tumorigenic potential of glioblastoma stem cells by activating STAT3. Cancer Cell. 2011;19:498-511.

44. Kortylewski M, Kujawski M, Herrmann A, Yang C, Wang L, Liu Y, et al. Toll-like receptor 9 activation of signal transducer and activator of transcription 3 constrains its agonist-based immunotherapy. Cancer Res. 2009;69:2497-505.

45. Eyking A, Ey B, Rünzi M, Roig Al, Reis H, Schmid KW, et al. Toll-like receptor 4 variant D299G induces features of neoplastic progression in Caco-2 intestinal cells and is associated with advanced human colon cancer. Gastroenterology. 2011;141:2154-65.

46. Lee H, Deng J, Kujawski M, Yang C, Liu Y, Herrmann A, et al. STAT3-induced S1PR1 expression is crucial for persistent STAT3 activation in tumors. Nat Med. 2010;16:1421-8.

47. Lee JL, Wang MJ, Chen JY. Acetylation and activation of STAT3 mediated by nuclear translocation of CD44. J Cell Biol. 2009;185:949-57.

48. Zheng L, Jia X, Zhang C, Wang D, Cao Z, Wang J, et al. Angiotensin II in atrial structural remodeling: the role of Ang II/JAK/STAT3 signaling pathway. Am J Transl Res. 2015;7:1021-31.

49. Geletu M, Arulanandam R, Chevalier S, Saez B, Larue L, Feracci H, et al. Classical cadherins control survival through the gp130/Stat3 axis. Biochim Biophys Acta. 2013;1833:1947-59.

50. Turkson J, Bowman T, Adnane J, Zhang Y, Djeu JY, Sekharam M, et al. Requirement for Ras/Rac1-mediated p38 and c-Jun N-terminal kinase signaling in Stat3 transcriptional activity induced by the Src oncoprotein. Mol Cell Biol. 1999:19:7519-28.

51. Chung J, Uchida E, Grammer TC, Blenis J. STAT3 serine phosphorylation by ERK-dependent and -independent pathways negatively modulates its tyrosine phosphorylation. Mol Cell Biol. 1997:17:6508-16.

52. Lim CP, Cao X. Serine phosphorylation and negative regulation of Stat3 by JNK. J Biol Chem. 1999;274:31055-61.

53. Jain N, Zhang T, Kee WH, Li W, Cao X. Protein kinase C delta associates with and phosphorylates Stat3 in an interleukin-6-dependent manner. J Biol Chem. 1999;274:24392-400.

54. Kim JH, Yoon MS, Chen J. Signal transducer and activator of transcription 3 (STAT3) mediates amino acid inhibition of insulin signaling through serine 727 phosphorylation. J Biol Chem. 2009;284:35425-32.

55. Wen Z, Zhong Z, Darnell JE. Maximal activation of transcription by Stat1 and Stat3 requires both tyrosine and serine phosphorylation. Cell. 1995;82:241-50.

56. Zhang X, Blenis J, Li HC, Schindler C, Chen-Kiang S. Requirement of serine phosphonylation for formation of STAT-promoter complexes. Science. 1995;267:1990-4.

57. Shi X, Zhang H, Paddon H, Lee G, Cao X, Pelech S. Phosphorylation of STAT3 serine-727 by cyclin-dependent kinase 1 is critical for nocodazole-induced mitotic arrest. Biochemistry. 2006;45:5857-67.

58. Androutsellis-Theotokis A, Leker RR, Soldner F, Hoeppner DJ, Ravin R, Poser SW, et al. Notch signalling regulates stem cell numbers in vitro and in vivo. Nature. 2006;442:823-6.

59. Liu H, Ma Y, Cole SM, Zander C, Chen KH, Karras J, et al. Serine phosphorylation of STAT3 is essential for Mcl-1 expression and macrophage survival. Blood. 2003:102:344-52.

60. Qin HR, Kim HJ, Kim JY, Hurt EM, Klarmann GJ, Kawasaki BT, et al. Activation of signal transducer and activator of transcription 3 through a phosphomimetic serine 727 promotes prostate tumorigenesis independent of tyrosine 705 phosphorylation. Cancer Res. 2008;68:7736-41.

61. Frank DA, Mahajan S, Ritz J. B lymphocytes from patients with chronic lymphocytic leukemia contain signal transducer and activator of transcription (STAT) 1 and STAT3 constitutively phosphorylated on serine residues. J Clin Invest. 1997;100:3140-8.

62. Hazan-Halevy I, Harris D, Liu Z, Liu J, Li P, Chen X, et al. STAT3 is constitutively phosphorylated on serine 727 residues, binds DNA, and activates transcription in CLL cells. Blood. 2010;115:2852-63.

63. Wegrzyn J, Potla R, Chwae YJ, Sepuri NB, Zhang Q, Koeck T, et al. Function of mitochondrial Stat3 in cellular respiration. Science. 2009;323:793-7.

64. Gough DJ, Corlett A, Schlessinger K, Wegrzyn J, Larner AC, Levy DE. Mitochondrial STAT3 supports Ras-dependent oncogenic transformation. Science. 2009;324:1713-6.

65. Liu L, McBride KM, Reich NC. STAT3 nuclear import is independent of tyrosine phosphorylation and mediated by importin-alpha3. Proc Natl Acad Sci U S A. 2005;102:8150-5.

66. Cimica V, Chen HC, lyer JK, Reich NC. Dynamics of the STAT3 transcription factor: nuclear import dependent on Ran and importin- $\beta 1$. PLoS One. 2011;6:e20188.

67. Butturini E, Gotte G, Dell'Orco D, Chiavegato G, Marino V, Canetti D, et al. Intermolecular disulfide bond influences unphosphorylated STAT3 dimerization and function. Biochem J. 2016;473(19):3205.

68. Timofeeva OA, Chasovskikh S, Lonskaya I, Tarasova NI, Khavrutskii L, Tarasov SG, et al. Mechanisms of unphosphorylated STAT3 transcription factor binding to DNA. J Biol Chem. 2012;287:14192-200.

69. Nkansah E, Shah R, Collie GW, Parkinson GN, Palmer J, Rahman KM, et al. Observation of unphosphorylated STAT3 core protein binding to target dsDNA by PEMSA and X-ray crystallography. FEBS Lett. 2013;587:833-9.

70. Yang J, Chatterjee-Kishore M, Staugaitis SM, Nguyen H, Schlessinger K, Levy DE, et al. Novel roles of unphosphorylated STAT3 in oncogenesis and transcriptional regulation. Cancer Res. 2005;65:939-47.

71. Yang J, Liao X, Agarwal MK, Barnes L, Auron PE, Stark GR. Unphosphorylated STAT3 accumulates in response to IL-6 and activates transcription by binding to NFkappaB. Genes Dev. 2007;21:1396-408.

72. Yuan ZL, Guan YJ, Chatterjee D, Chin YE. Stat3 dimerization regulated by reversible acetylation of a single lysine residue. Science. 2005;307:269-73. 
73. Wang R, Cherukuri P, Luo J. Activation of Stat3 sequence-specific DNA binding and transcription by p300/CREBbinding protein-mediated acetylation. J Biol Chem. 2005;280:11528-34.

74. Dasgupta M, Unal H, Willard B, Yang J, Karnik SS, Stark GR. Critical role for lysine 685 in gene expression mediated by transcription factor unphosphorylated STAT3. J Biol Chem. 2014;289:30763-71.

75. Kim E, Kim M, Woo DH, Shin Y, Shin J, Chang N, et al. Phosphorylation of EZH2 activates STAT3 signaling via STAT3 methylation and promotes tumorigenicity of glioblastoma stem-like cells. Cancer Cell. 2013;23:839-52.

76. Su F, Ren F, Rong Y, Wang Y, Geng Y, Feng M, et al. Protein tyrosine phosphatase Meg2 dephosphorylates signal transducer and activator of transcription 3 and suppresses tumor growth in breast cancer. Breast Cancer Res. 2012;14:R38.

77. Kumar V, Cheng P, Condamine T, Mony S, Languino LR, McCaffrey JC, et al. CD45 Phosphatase Inhibits STAT3 Transcription Factor Activity in Myeloid Cells and Promotes Tumor-Associated Macrophage Differentiation. Immunity. 2016;44:303-15.

78. Kim DJ, Tremblay ML, Digiovanni J. Protein tyrosine phosphatases, TC-PTP, SHP1, and SHP2, cooperate in rapid dephosphorylation of Stat3 in keratinocytes following UVB irradiation. PLoS One. 2010;5:e10290.

79. Zgheib C, Zouein FA, Chidiac R, Kurdi M, Booz GW. Calyculin A reveals serine/threonine phosphatase protein phosphatase 1 as a regulatory nodal point in canonical signal transducer and activator of transcription 3 signaling of human microvascular endothelial cells. J Interferon Cytokine Res. 2012;32:87-94.

80. Lu D, Liu L, Ji X, Gao Y, Chen X, Liu Y, et al. The phosphatase DUSP2 controls the activity of the transcription activator STAT3 and regulates TH17 differentiation. Nat Immunol. 2015;16:1263-73.

81. Yuan J, Zhang F, Niu R. Multiple regulation pathways and pivotal biological functions of STAT3 in cancer. Sci Rep. 2015:5:17663.

82. Nicholson SE, De Souza D, Fabri L, Corbin J, Willson TA, Zhang JG, et al. Suppressor of cytokine signaling-3 preferentially binds to the SHP-2-binding site on the shared cytokine receptor subunit gp130. Proc Natl Acad Sci U S A. 2000;97:6493-8,

83. Lee JH, Kim C, Sethi G, Ahn KS. Brassinin inhibits STAT3 signaling pathway through modulation of PIAS-3 and SOCS-3 expression and sensitizes human lung cancer xenograft in nude mice to paclitaxel. Oncotarget. 2015;6:6386-405.

84. Chung CD, Liao J, Liu B, Rao X, Jay P, Berta P, et al. Specific inhibition of Stat3 signal transduction by PIAS3. Science. 1997;278:1803-5.

85. Yang J, Huang J, Dasgupta M, Sears N, Miyagi M, Wang B, et al. Reversible methylation of promoter-bound STAT3 by histone-modifying enzymes. Proc Natl Acad Sci U S A. 2010;107:21499-504.

86. Yu H, Lee H, Herrmann A, Buettner R, Jove R. Revisiting STAT3 signalling in cancer: new and unexpected biological functions. Nat Rev Cancer. 2014;14:736-46.

87. Cai B, Li J, Wang J, Luo X, Ai J, Liu Y, et al. microRNA-124 regulates cardiomyocyte differentiation of bone marrow-derived mesenchymal stem cells via targeting STAT3 signaling. Stem Cells. 2012;30:1746-55.

88. Jiang J, Li Z, Yu C, Chen M, Tian S, Sun C. MiR-1181 inhibits stem cell-like phenotypes and suppresses SOX2 and STAT3 in human pancreatic cancer. Cancer Lett. 2015;356:962-70.

89. Zhang H, Cai K, Wang J, Wang X, Cheng K, Shi F, et al. MiR-7, inhibited indirectly by lincRNA HOTAIR, directly inhibits SETDB1 and reverses the EMT of breast cancer stem cells by downregulating the STAT3 pathway. Stem Cells. 2014;32:2858-68.

90. Pawlus MR, Wang L, Hu CJ. STAT3 and HIF1a cooperatively activate HIF1 target genes in MDA-MB-231 and RCC4 cells. Oncogene. 2014;33:1670-9.

91. Reya T, Morrison SJ, Clarke MF, Weissman IL. Stem cells, cancer, and cancer stem cells. Nature. 2001;414:105-11.

92. Takahashi K, Yamanaka S. Induction of pluripotent stem cells from mouse embryonic and adult fibroblast cultures by defined factors. Cell. 2006;126:663-76.

93. Humphrey RK, Beattie GM, Lopez AD, Bucay N, King CC, Firpo MT, et al. Maintenance of pluripotency in human embryonic stem cells is STAT3 independent. Stem Cells. 2004;22:522-30.

94. Davis S, Aldrich TH, Stahl N, Pan L, Taga T, Kishimoto T, et al. LIFR beta and gp130 as heterodimerizing signal transducers of the tripartite CNTF receptor. Science. 1993;260:1805-8.

95. Matsuda T, Nakamura T, Nakao K, Arai T, Katsuki M, Heike T, et al. STAT3 activation is sufficient to maintain an undifferentiated state of mouse embryonic stem cells. EMBO J. 1999;18:4261-9.

96. Raz R, Lee CK, Cannizzaro LA, d'Eustachio P, Levy DE. Essential role of STAT3 for embryonic stem cell pluripotency. Proc Natl Acad Sci U S A. 1999;96:2846-51.

97. Cartwright P, McLean C, Sheppard A, Rivett D, Jones K, Dalton S. LIF/STAT3 controls ES cell self-renewal and pluripotency by a Myc-dependent mechanism. Development. 2005;132:885-96.

98. Chen CY, Lee DS, Yan YT, Shen CN, Hwang SM, Lee ST, et al. BCl3 Bridges LIF-STAT3 to Oct4 Signaling in the Maintenance of Naiive Pluripotency. Stem Cells. 2015;33:3468-80.

99. Torres J, Watt FM. Nanog maintains pluripotency of mouse embryonic stem cells by inhibiting NFkappaB and cooperating with Stat3. Nat Cell Biol. 2008;10:194-201.

100. Huang G, Yan H, Ye S, Tong C, Ying QL. STAT3 phosphorylation at tyrosine 705 and serine 727 differentially regulates mouse ESC fates. Stem Cells. 2014;32:1149-60.

101. Gu F, Hata R, Ma YJ, Tanaka J, Mitsuda N, Kumon Y, et al. Suppression of Stat3 promotes neurogenesis in cultured neural stem cells. J Neurosci Res. 2005;81:163-71.

102. Kamakura S, Oishi K, Yoshimatsu T, Nakafuku M, Masuyama N, Gotoh Y. Hes binding to STAT3 mediates crosstalk between Notch and JAK-STAT signalling. Nat Cell Biol. 2004;6:547-54.

103. Yoshimatsu T, Kawaguchi D, Oishi K, Takeda K, Akira S, Masuyama N, et al. Non-cell-autonomous action of STAT3 in maintenance of neural precursor cells in the mouse neocortex. Development. 2006;133:2553-63.

104. Chung YJ, Park BB, Kang YJ, Kim TM, Eaves CJ, Oh IH. Unique effects of Stat3 on the early phase of hematopoietic stem cell regeneration. Blood. 2006;108:1208-15.

105. Zhu H, Xiao F, Wang G, Wei X, Jiang L, Chen Y, et al. STAT3 Regulates Self-Renewal of Adult Muscle Satellite Cells during Injury-Induced Muscle Regeneration. Cell Rep. 2016;16:2102-15.

106. Tadokoro T, Wang Y, Barak LS, Bai Y, Randell SH, Hogan BL. IL-6/STAT3 promotes regeneration of airway ciliated cells from basal stem cells. Proc Natl Acad Sci U S A. 2014;111:E3641-9.

107. Yuan Y, Xi Y, Chen J, Zhu P, Kang J, Zou Z, et al. STAT3 stimulates adipogenic stem cell proliferation and cooperates with HMGA2 during the early stage of differentiation to promote adipogenesis. Biochem Biophys Res Commun. 2017:482:1360-6. 
108. Chen Q, Quan Y, Wang N, Xie C, Ji Z, He H, et al. Inactivation of STAT3 Signaling Impairs Hair Cell Differentiation in the Developing Mouse Cochlea. Stem Cell Reports. 2017;9:231-46.

109. Staniszewska AD, Pensa S, Caffarel MM, Anderson LH, Poli V, Watson CJ. Stat3 is required to maintain the full differentiation potential of mammary stem cells and the proliferative potential of mammary luminal progenitors. PLoS One. 2012;7:e52608.

110. Dahéron L, Opitz SL, Zaehres H, Lensch MW, Lensch WM, Andrews PW, et al. LIF/STAT3 signaling fails to maintain self-renewal of human embryonic stem cells. Stem Cells. 2004;22:770-8.

111. Yang J, van Oosten AL, Theunissen TW, Guo G, Silva JC, Smith A. Stat3 activation is limiting for reprogramming to ground state pluripotency. Cell Stem Cell. 2010;7:319-28.

112. Chen H, Aksoy I, Gonnot F, Osteil P, Aubry M, Hamela C, et al. Reinforcement of STAT3 activity reprogrammes human embryonic stem cells to naive-like pluripotency. Nat Commun. 2015;6:7095.

113. Matsui F, Babitz SA, Rhee A, Hile KL, Zhang H, Meldrum KK. Mesenchymal stem cells protect against obstructioninduced renal fibrosis by decreasing STAT3 activation and STAT3-dependent MMP-9 production. Am J Physiol Renal Physiol. 2017;312:F25-32.

114. Hsu HS, Lin JH, Hsu TW, Su K, Wang CW, Yang KY, et al. Mesenchymal stem cells enhance lung cancer initiation through activation of IL-6/JAK2/STAT3 pathway. Lung Cancer. 2012;75:167-77.

115. Rattigan Y, Hsu JM, Mishra PJ, Glod J, Banerjee D. Interleukin 6 mediated recruitment of mesenchymal stem cells to the hypoxic tumor milieu. Exp Cell Res. 2010;316:3417-24.

116. Buettner R, Mora LB, Jove R, Activated STAT. signaling in human tumors provides novel molecular targets for therapeutic intervention. Clin Cancer Res. 2002;8:945-54.

117. Marotta LL, Almendro V, Marusyk A, Shipitsin M, Schemme J, Walker SR, et al. The JAK2/STAT3 signaling pathway is required for growth of CD44 ${ }^{+}$CD24 stem cell-like breast cancer cells in human tumors. J Clin Invest. 2011;121:2723-35.

118. Forbes SA, Beare D, Boutselakis H, Bamford S, Bindal N, Tate J, et al. COSMIC: somatic cancer genetics at highresolution. Nucleic Acids Res. 2017;45:D777-D83.

119. Xiong H, Du W, Wang JL, Wang YC, Tang JT, Hong J, et al. Constitutive activation of STAT3 is predictive of poor prognosis in human gastric cancer. J Mol Med (Berl). 2012;90:1037-46.

120. Mora LB, Buettner R, Seigne J, Diaz J, Ahmad N, Garcia R, et al. Constitutive activation of Stat3 in human prostate tumors and cell lines: direct inhibition of Stat3 signaling induces apoptosis of prostate cancer cells. Cancer Res. 2002;62:6659-66.

121. Masuda M, Suzui M, Yasumatu R, Nakashima T, Kuratomi Y, Azuma K, et al. Constitutive activation of signal transducers and activators of transcription 3 correlates with cyclin D1 overexpression and may provide a novel prognostic marker in head and neck squamous cell carcinoma. Cancer Res. 2002;62:3351-5.

122. Györffy B, Lanczky A, Eklund AC, Denkert C, Budczies J, Li Q, et al. An online survival analysis tool to rapidly assess the effect of 22,277 genes on breast cancer prognosis using microarray data of 1,809 patients. Breast Cancer Res Treat. 2010;123:725-31.

123. Lánczky A, Nagy Á, Bottai G, Munkácsy G, Szabó A, Santarpia L, et al. miRpower: a web-tool to validate survival-associated miRNAs utilizing expression data from 2178 breast cancer patients. Breast Cancer Res Treat. 2016;160:439-46.

124. Rosen JM, Jordan CT. The increasing complexity of the cancer stem cell paradigm. Science. 2009;324:1670-3.

125. Korkaya H, Liu S, Wicha MS. Regulation of cancer stem cells by cytokine networks: attacking cancer's inflammatory roots. Clin Cancer Res. 2011;17:6125-9.

126. Badve S, Nakshatri H. Breast-cancer stem cells-beyond semantics. Lancet Oncol. 2012;13:e43-8.

127. Pattabiraman DR, Weinberg RA. Tackling the cancer stem cells - what challenges do they pose? Nat Rev Drug Discov. 2014;13:497-512.

128. Nassar D, Blanpain C. Cancer Stem Cells: Basic Concepts and Therapeutic Implications. Annu Rev Pathol. 2016;11:47-76.

129. Foulkes WD, Smith IE, Reis-Filho JS. Triple-negative breast cancer. N Engl J Med. 2010;363:1938-48.

130. Lin L, Fuchs J, Li C, Olson V, Bekail-Saab T, Lin J. STAT3 signaling pathway is necessary for cell survival and tumorsphere forming capacity in $\mathrm{ALDH}^{+} / \mathrm{CD} 133^{+}$stem celll-ike human colon cancer cells. Biochem Biophys Res Commun. 2011;416:246-51.

131. Schroeder A, Herrmann A, Cherryholmes G, Kowolik C, Buettner R, Pal S, et al. Loss of androgen receptor expression promotes a stem-like cell phenotype in prostate cancer through STAT3 signaling. Cancer Res. 2014;74:1227-37.

132. Su YJ, Lai HM, Chang YW, Chen GY, Lee JL. Direct reprogramming of stem cell properties in colon cancer cells by CD44. EMBO J. 2011;30:3186-99.

133. Chung SS, Aroh C, Vadgama JV. Constitutive activation of STAT3 signaling regulates hTERT and promotes stem cell-like traits in human breast cancer cells. PLoS One. 2013;8:e83971.

134. Won C, Kim BH, Yi EH, Choi KJ, Kim EK, Jeong JM, et al. Signal transducer and activator of transcription 3-mediated CD133 up-regulation contributes to promotion of hepatocellular carcinoma. Hepatology. 2015;62:1160-73.

135. Gupta PB, Chaffer CL, Weinberg RA. Cancer stem cells: mirage or reality? Nat Med. 2009;15:1010-2.

136. Singh A, Settleman J. EMT, cancer stem cells and drug resistance: an emerging axis of evil in the war on cancer. Oncogene. 2010;29:4741-51.

137. Mani SA, Guo W, Liao MJ, Eaton EN, Ayyanan A, Zhou AY, et al. The epithelial-mesenchymal transition generates cells with properties of stem cells. Cell. 2008;133:704-15.

138. Morel AP, Lièvre M, Thomas C, Hinkal G, Ansieau S, Puisieux A. Generation of breast cancer stem cells through epithelial-mesenchymal transition. PLoS One. 2008;3:e2888.

139. Wang SS, Jiang J, Liang XH, Tang YL. Links between cancer stem cells and epithelial-mesenchymal transition. Onco Targets Ther. 2015;8:2973-80.

140. Vazquez-Santillan K, Melendez-Zajgla J, Jimenez-Hernandez L, Martínez-Ruiz G, Maldonado V. NF-kB signaling in cancer stem cells: a promising therapeutic target? Cell Oncol (Dordr). 2015;38:327-39.

141. Tang Y, Kitisin K, Jogunoori W, Li C, Deng CX, Mueller SC, et al. Progenitor/stem cells give rise to liver cancer due to aberrant TGF-beta and IL-6 signaling. Proc Natl Acad Sci U S A. 2008;105:2445-50.

142. Gujral TS, Chan M, Peshkin L, Sorger PK, Kirschner MW, MacBeath G. A noncanonical Frizzled2 pathway regulates epithelial-mesenchymal transition and metastasis. Cell. 2014;159:844-56.

143. Peñuelas S, Anido J, Prieto-Sánchez RM, Folch G, Barba I, Cuartas I, et al. TGF-beta increases glioma-initiating cell self-renewal through the induction of LIF in human glioblastoma. Cancer Cell. 2009;15:315-27. 
144. Liu WH, Chen MT, Wang ML, Lee YY, Chiou GY, Chien CS, et al. Cisplatin-selected resistance is associated with increased motility and stem-like properties via activation of STAT3/Snail axis in atypical teratoid/rhabdoid tumor cells. Oncotarget. 2015;6:1750-68.

145. Chung SS, GiehI N, WU Y, Vadgama JV. STAT3 activation in HER2-overexpressing breast cancer promotes epithelialmesenchymal transition and cancer stem cell traits. Int J Oncol. 2014;44:403-11.

146. Korkaya H, Kim Gl, Davis A, Malik F, Henry NL, Ithimakin S, et al. Activation of an IL6 inflammatory loop mediates trastuzumab resistance in HER2+ breast cancer by expanding the cancer stem cell population. Mol Cell. 2012;47:570-84

147. Aghazadeh S, Yazdanparast R. Activation of STAT3/HIF-1a/Hes-1 axis promotes trastuzumab resistance in HER2overexpressing breast cancer cells via down-regulation of PTEN. Biochim Biophys Acta. 2017;1861:1970-80.

148. Zhou J, Wulfkuhle J, Zhang H, Gu P, Yang Y, Deng J, et al. Activation of the PTEN/mTOR/STAT3 pathway in breast cancer stem-like cells is required for viability and maintenance. Proc Natl Acad Sci U S A. 2007;104:16158-63.

149. Moon SH, Kim DK, Cha Y, Jeon I, Song J, Park KS. PI3K/Akt and Stat3 signaling regulated by PTEN control of the cancer stem cell population, proliferation and senescence in a glioblastoma cell line. Int J Oncol. 2013;42:921-8.

150. Fantozzi A, Gruber DC, Pisarsky L, Heck C, Kunita A, Yilmaz M, et al. VEGF-mediated angiogenesis links EMTinduced cancer stemness to tumor initiation. Cancer Res. 2014;74:1566-75.

151. Jinushi M, Chiba S, Yoshiyama H, Masutomi K, Kinoshita I, Dosaka-Akita H, et al. Tumor-associated macrophages regulate tumorigenicity and anticancer drug responses of cancer stem/initiating cells. Proc Natl Acad Sci U S A. 2011;108(30):12425

152. Yang J, Liao D, Chen C, Liu Y, Chuang TH, Xiang R, et al. Tumor-associated macrophages regulate murine breast cancer stem cells through a novel paracrine EGFR/Stat3/Sox-2 signaling pathway. Stem Cells. 2013;31:248-58.

153. Attarha S, Roy A, Westermark B, Tchougounova E. Mast cells modulate proliferation, migration and stemness of glioma cells through downregulation of GSK3 $\beta$ expression and inhibition of STAT3 activation. Cell Signal. 2017;37:81-92.

154. Islam M, Sharma S, Teknos TN. RhoC regulates cancer stem cells in head and neck squamous cell carcinoma by overexpressing IL-6 and phosphorylation of STAT3. PLoS One. 2014;9:e88527.

155. Zhao C, Li H, Lin HJ, Yang S, Lin J, Liang G. Feedback Activation of STAT3 as a Cancer Drug-Resistance Mechanism. Trends Pharmacol Sci. 2016:37:47-61.

156. Yang F, Van Meter TE, Buettner R, Hedvat M, Liang W, Kowolik CM, et al. Sorafenib inhibits signal transducer and activator of transcription 3 signaling associated with growth arrest and apoptosis of medulloblastomas. Mol Cancer Ther. 2008;7:3519-26.

157. Nefedova Y, Nagaraj S, Rosenbauer A, Muro-Cacho C, Sebti SM, Gabrilovich DI. Regulation of dendritic cell differentiation and antitumor immune response in cancer by pharmacologic-selective inhibition of the janus-activated kinase 2/signal transducers and activators of transcription 3 pathway. Cancer Res. 2005;65:9525-35.

158. Yang A, Kaghad M, Wang Y, Gillett E, Fleming MD, Dötsch V, et al. p63, a p53 homolog at 3q27-29, encodes multiple products with transactivating, death-inducing, and dominant-negative activities. Mol Cell. 1998;2:305-16.

159. Chu WK, Dai PM, Li HL, Chen JK. Transcriptional activity of the DeltaNp63 promoter is regulated by STAT3. J Biol Chem. 2008;283:7328-37.

160. Rufini S, Lena AM, Cadot B, Mele S, Amelio I, Terrinoni A, et al. The sterile alpha-motif (SAM) domain of p63 binds in vitro monoasialoganglioside (GM1) micelles. Biochem Pharmacol. 2011;82:1262-8.

161. Sayan BS, Sayan AE, Yang AL, Aqeilan Rl, Candi E, Cohen GM, et al. Cleavage of the transactivation-inhibitory domain of p63 by caspases enhances apoptosis. Proc Natl Acad Sci U S A. 2007;104:10871-6.

162. Mills AA, Zheng B, Wang XJ, Vogel H, Roop DR, Bradley A. p63 is a p53 homologue required for limb and epidermal morphogenesis. Nature. 1999;398:708-13.

163. Yang A, Schweitzer R, Sun D, Kaghad M, Walker N, Bronson RT, et al. p63 is essential for regenerative proliferation in limb, craniofacial and epithelial development. Nature. 1999;398:714-8.

164. Pignon JC, Grisanzio C, Geng Y, Song J, Shivdasani RA, Signoretti S. p63-expressing cells are the stem cells of developing prostate, bladder, and colorectal epithelia. Proc Natl Acad Sci U S A. 2013;110:8105-10.

165. Liu K, Jiang M, Lu Y, Chen H, Sun J, Wu S, et al. Sox2 cooperates with inflammation-mediated Stat3 activation in the malignant transformation of foregut basal progenitor cells. Cell Stem Cell. 2013;12:304-15.

166. Sethi I, Sinha S, Buck MJ. Role of chromatin and transcriptional co-regulators in mediating p63-genome interactions in keratinocytes. BMC Genomics. 2014;15:1042.

167. Wu M, Wang B, Gil J, Sabo E, Miller L, Gan L, et al. p63 and TTF-1 immunostaining. A useful marker panel for distinguishing small cell carcinoma of lung from poorly differentiated squamous cell carcinoma of lung. Am J Clin Pathol. 2003;119:696-702.

168. Chakrabarti R, Wei Y, Hwang J, Hang X, Andres Blanco M. Choudhury A, et al. $\Delta$ Np63 promotes stem cell activity in mammary gland development and basal-like breast cancer by enhancing Fzd7 expression and Wnt signalling. Nat Cell Biol. 2014; 16. 1004-15:1-13.

169. Koster MI, Lu SL, White LD, Wang XJ, Roop DR. Reactivation of developmentally expressed p63 isoforms predisposes to tumor development and progression. Cancer Res. 2006;66:3981-6.

170. Wei W, Tweardy DJ, Zhang M, Zhang X, Landua J, Petrovic I, et al. STAT3 signaling is activated preferentially in tumor-initiating cells in claudin-low models of human breast cancer. Stem Cells. 2014;32:2571-82.

171. Hajimoradi M, Mohammad Hassan Z, Ebrahimi M, Soleimani M, Bakhshi M, Firouzi J, et al. STAT3 is Overactivated in Gastric Cancer Stem-Like Cells. Cell J. 2016;17:617-28.

172. Sriuranpong V, Park Jl, Amornphimoltham P, Patel V, Nelkin BD, Gutkind JS. Epidermal growth factor receptorindependent constitutive activation of STAT3 in head and neck squamous cell carcinoma is mediated by the autocrine/paracrine stimulation of the interleukin 6/gp130 cytokine system. Cancer Res. 2003;63:2948-56.

173. Thiagarajan PS, Zheng Q, Bhagrath M, Mulkearns-Hubert EE, Myers MG, Lathia JD, et al. STAT3 activation by leptin receptor is essential for TNBC stem cell maintenance. Endocr Relat Cancer. 2017;24:415-26.

174. Chu WK, Lee KC, Chow SE, Chen JK. Dual regulation of the DeltaNp63 transcriptional activity by DeltaNp63 in human nasopharyngeal carcinoma cell. Biochem Biophys Res Commun. 2006;342:1356-60.

175. Hsueh YJ, Chen HC, Chu WK, Cheng CC, Kuo PC, Lin LY, et al. STAT3 regulates the proliferation and differentiation of rabbit limbal epithelial cells via a $\Delta$ Np63-dependent mechanism. Invest Ophthalmol Vis Sci. 2011;52:4685-93. 
176. Ripamonti F, Albano L, Rossini A, Borrelli S, Fabris S, Mantovani R, et al. EGFR through STAT3 modulates $\Delta$ N63a expression to sustain tumor-initiating cell proliferation in squamous cell carcinomas. J Cell Physiol. 2013;228:871-8.

177. Ma J, Meng Y, Kwiatkowski DJ, Chen X, Peng H, Sun Q, et al. Mammalian target of rapamycin regulates murine and human cell differentiation through STAT3/p63/Jagged/Notch cascade. J Clin Invest. 2010;120:103-14.

178. King KE, Ponnamperuma RM, Allen C, Lu H, Duggal P, Chen Z, et al. The p53 homologue DeltaNp63alpha interacts with the nuclear factor-kappaB pathway to modulate epithelial cell growth. Cancer Res. 2008;68:5122-31.

179. Yang X. Lu H, Yan B, Romano RA, Bian Y, Friedman J, et al. $\Delta$ Np63 versatilely regulates a Broad NF-kB gene program and promotes squamous epithelial proliferation, migration, and inflammation. Cancer Res. 2011;71:3688-700.

180. Senoo M, Matsumura Y, Habu S. TAp63gamma (p51A) and dNp63alpha (p73L), two major isoforms of the p63 gene, exert opposite effects on the vascular endothelial growth factor (VEGF) gene expression. Oncogene. 2002;21:2455-65.

181. Stacy AJ, Craig MP, Sakaram S, Kadakia M. $\Delta$ Np63a and microRNAs: leveraging the epithelial-mesenchymal transition. Oncotarget. 2017;8:2114-29.

182. Sasaki Y, Ishida S, Morimoto I, Yamashita T, Kojima T, Kihara C, et al. The p53 family member genes are involved in the Notch signal pathway. J Biol Chem. 2002;277:719-24.

183. Su X, Napoli M, Abbas HA, Venkatanarayan A, Bui NHB, Coarfa C, et al. TAp63 suppresses mammary tumorigenesis through regulation of the Hippo pathway. Oncogene. 2017;36:2377-93.

\section{Submit your next manuscript to BioMed Central and we will help you at every step:}

- We accept pre-submission inquiries

- Our selector tool helps you to find the most relevant journal

- We provide round the clock customer support

- Convenient online submission

- Thorough peer review

- Inclusion in PubMed and all major indexing services

- Maximum visibility for your research

Submit your manuscript at www.biomedcentral.com/submit 